In a review as short as this, applications can be only briefly indicated. For industry, important advantages are, first, that a sample may be examined without destroying or indeed interfering with it, and that very small quantities are required, and secondly, that since the spectrum between, let us say, $1 \mu$ and 30 is a unique property of any given substance, that spectrum may irf principle be used to identify the substance in any mixture in which it remains unaltered. In favourable cases concentrations as low as 1 in 10,000 may be recognized. If the substance is modified in the mixture, by association or otherwise, then its spectrum reflects the change and may be used as a source of information about it. So far as pure science is concerned, the greatest application of infra-red research in the near future will probably be made in conjunction with isotope chemistry, at first with deutero-substituted compounds, but later with other isotopes, carbon, nitrogen and oxygen in particular, as fast as they are made available in quantity. With this technique a knowledge of reaction mechanisms will be obtained which would scarcely be possible by any other method.

\title{
THE FENLAND*
}

\section{By Prof. J. Stanley Gardiner, F.R.S.}

$\mathrm{T}$ HE Fenland is an area of 73 miles by 36 miles, covering 1306 square miles, and comprises parts of the counties of Lincoln, Norfolk, Suffolk, Cambridge, Huntingdon and Northampton. It consists of Jurassic clays underlying glacial boulder clay, cut into basins and water courses by tidal and river actions. Some Jurassic islands were left, such as Ely, while peat formed in the swamps to the south, merging into a broad belt of silt against the sea. The area was not stable, and peat and silt in places alternate ; and often horizons of submerged forests are followed by swamp conditions. In the earliest period of history the Fenland was a flat expanse with scattered islands and ridges from the surrounding uplands, all these cultivated, while the swamps yielded rough produce for stock, the streams abundant fish, especially eels, and the marshes wild-fowl. Of course it must have been a paradise to the Romans by providing an outlet for their energies, the results of which are problematical. It is only certain that there was wide cultivation succeeded by decay. This was possibly due to the neglect of drainage works, complicated by a small change in land-level in progress towards the termination of the Roman occupation.

In the Norman period the condition of the Fenland may be inferred from the map of the Domesday settlements. It must have been affected by the relatively recent monastic foundations of Crowland, Ely, Ramsay, Thorney and Chatteris. For his recently issued studies on the Fenland, Mr. Darby has consulted all authorities, but they have helped little as to the economy in this AngloDanish period. His inferences are based on the Domesday settlement-peat lands do not allow

- The Medieval Fenland. By H. C. Darby. (Cambridge Studies In Economic History). Pp. xvii $+200+11$ plates. (Cambridge : At the University Press, 1940). 128. 6d. net.

The Draining of the Fens. By $\mathbf{H}$. C. Darby. (Cambridge Studies in Economic History). Pp. xix $+312+31$ plates. (Cambridge: At the University Press, 1940). 218, net. of the building of house foundations-the sizes of parishes and the distributions of fisheries, salt pans, meadow and other lands. The Wisbech estuary now became silted up and inundations followed. At some uncertain date the Eastern and Western Ouses were diverted, partly by artificial channels, to reach the sea at Lynn. Traffic to the surrounding lands apparently thronged the waterways. In the fourteenth century the Fenland was many times more prosperous than the surrounding upland. Strategically, it might be a centre of rebellion or of refugea comparison with part of southern Finland to-day is not inappropriate-but disturbances were largely dictated by neighbouring barons. Socially, there was no isolation and its people were not "endowed with any qualities of desperate wildness extracted by some mystical influence from reeds and rushes". Mr. Darby's economic study of this time is excellent, but he could have made it plainer to his readers had he presented a picture of the Fenland as it really was, its meandering rivers, open pools, marshes, sedge and litter lands, thickets and woods. Its peat is not the well-known product of moss but of the decay of sedge and litter; it is very alkaline.

The account of Tudor times in the Fens reveals a woeful condition of dire poverty. This was partially due to the upheaval that succeeded the dissolution of the monasteries, but every 'Court' was quite ineffective in maintaining the Fenland channels and drains. Parliament became interested in the matter and in 1534 passed the first Act for the preservation of birds ; wild-fowl were given a close season in June, July and August, and the taking of their eggs was prohibited "upon pain of imprisonment for one year". Later, there were great floods and many permanent 'drownings', and in $\mathbf{1 5 7 0}$ the sea broke in near Wisbech. Drainage 
thus became a matter of national rather than parochial interest, the first effort being concentrated on cleaning out the channels and repairing the banks near Wisbech.

The interest of King James resulted in a welter of ineffective activity. In 1630 the Earl of Bedford 'adventured' his money to drain the southern fens, now known as the Bedford Level. $\mathrm{He}$ employed that Vermuyden whom the Commissioners had previously refused to employ. His plan was to shorten the courses of the main streams so as to increase their gradients, erecting the necessary sluices to control the tides. In 1631 the Bedford River, a straight channel 21 miles long from Earith to Denver, was dug ; it was completed twenty years later by a strongly embanked second channel. I may say that in the nineteenth century it attained peculiar fame, for here a great

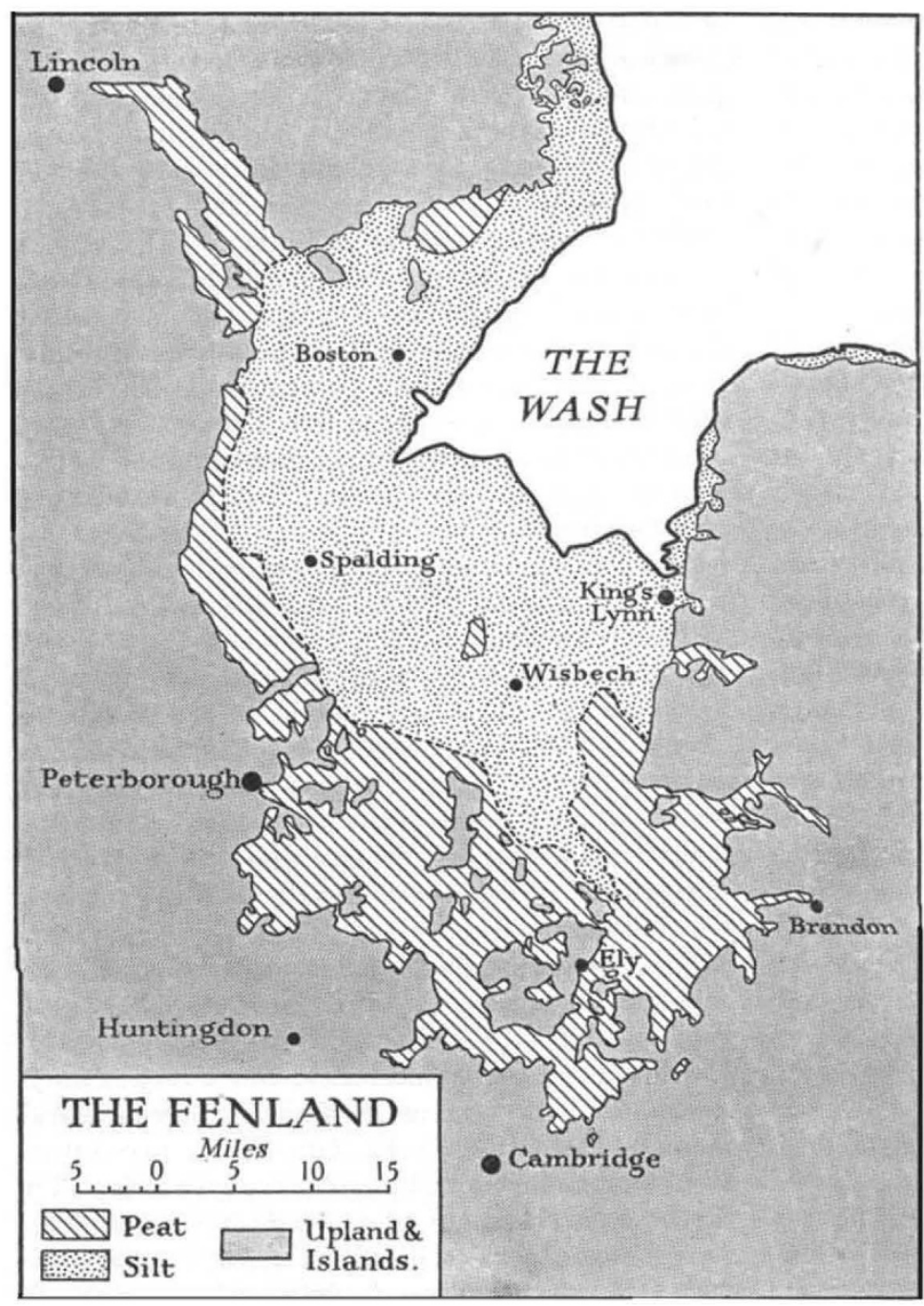

Fig. 1.

From "The Medieval Fenland".

THE PRESENT-DAY DISTRIBUTION OF THE LAND. controversy as to the rotundity of the earth was settled by A.R.Wallace (see Nature, April 6, p.561).

Other projects were a "Middle Level" from Peterborough and a "Northern Cut"; the Earl of Lindsey was at work on the Lincoln fens. Everywhere there were disturbances as the whole economy of the region was upset, and "Mr. Cromwell" appeared at Huntingdon in 1638 as the chief opponent of King Charles, who was the "undertaker". Later Cromwell established himself at Ely, so that in the Civil War the Fens were not a harbour of refuge ; of course all work ceased and there was much destruction. Internal peace encouraged a resumption of drainage in the southern Fenland, and Cromwell, now the statesman and great patriot, supplied both Scottish and Danish prisoners as labour; German prisoners were used similarly in 1917-18.

Innumerable difficulties were experienced in the eighteenth century due to the necessity of preserving channels for navigation, the inefficiency of the control of the outfalls to the sea, the looseness of the banks-this allowed a constant seepageand, above all, the settling of the ground surface in the peat lands. The latter now lay considerably below the river-levels and the water channels that had been cut to carry the upland drainage into the rivers. Such shrinkage was experienced but slightly over the silt lands of Lincolnshire, so that the problems there were never so difficult as over the southern Fenland. For example, Wicken Sedge Fen is a catchment basin for the waters of its adjoining uplands, which are retained by means of the lodes and ditches surrounding it, while the surface of the peat lands of the neighbouring Burwell Fen now lies $7 \mathrm{ft}$. below, this difference representing the shrinkage*.

Nearer the centre of the Fenland in 1851 a column was inserted near Whittlesea Mere to the level of the peat surface. The mere was pumped by the new Appold system, and in three weeks 1,000 acres almost $3 \mathrm{ft}$. deep were drained ; the column now

* "On the Level of the Fens around Wicken", by W. S. Farren, "Natural History of Wicken Fen", 190 et seq (1926). This is the part of the Fenland which best retains the conditions preceding the drainage. The vegetation is considered by Messrs. Godwin and Tansley, and the animal life by Dr. A. H. Evans and more than thirty other authors. These volumes have escaped Mr. Darby's bibliography. 
stands $11 \mathrm{ft}$. above the surface of the ground, and there is $11 \mathrm{ft}$. of peat below. "The better the drainage, the greater the wastage of the peat surface", as Darby expresses it. A remedy was found ; the picturesque wooden windmills being built in the eighteenth century replaced ponies in raising the water from ditches in the lower Fenlands to the drainage lodes, which were straightened still more and strengthened; the outfalls with the necessary sluices were likewise improved.

Even at the end of the eighteenth century, conditions in respect to flooding were bad, as Young tells us, but the reclaimed land was the richest in England for corn and stock. Only a few years later the advent of the steam engine gave man the necessary power of control. An inscription on a pumping station of the New Bedford River reads :

These Fens have oft times been by Water drown'd,

Science a remedy in Water found. The powers of Steam she said shall be

And the Destroyer by Itself destroyed.

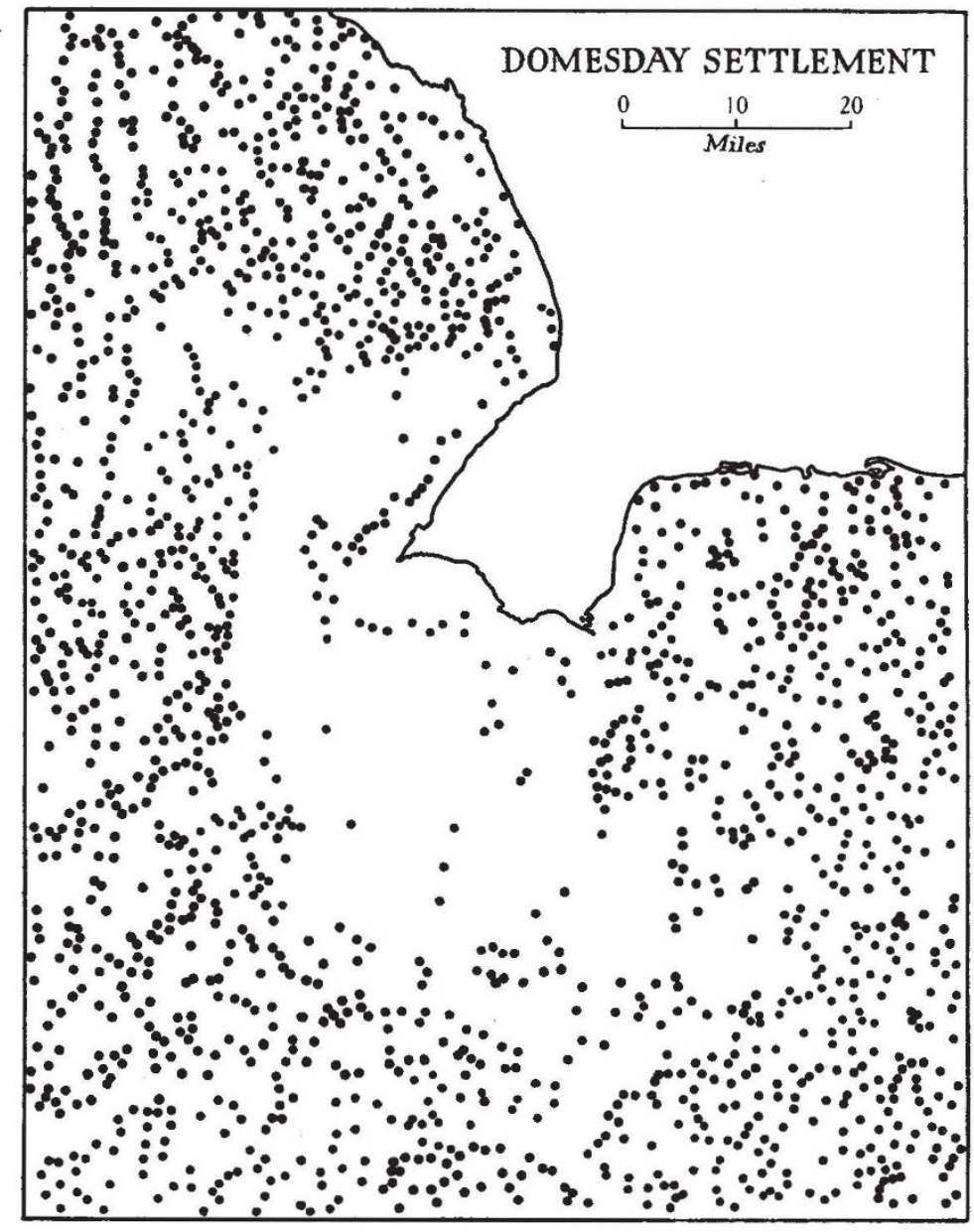

Fig. 2.

From "The Medieval Fenland"

The setrlements of the peat were upon the islands (See Fig. 1). The Breckland COUntry to the east WAS very sCantily SETtLed. on occasions, even in the last decade every fenman near Ely has been called out to work both by night and day, while some houses were evacuated; even troops and undergraduates from Cambridge were summoned to help in saving the banks, and hourly bulletins were issued. In these later days the control of the sea was better understood, but the problem here was vastly different from that of the Zuider Zee. The Fenland with its islands carried a considerable population, while the Wash, with its strong tides and open waters, makes the building of any large controlling dam, while quite unthinkable centuries ago, almost impossible even to-day.

Mr. Darby is to be congratulated on his remarkable study of the Fens. His every historical statement is supported by reference and selected with a real grasp of essentials. A chapter showing why the reclamation of the Fens became a national rather than a local matter would have helped in the study of his research. We should also like to know more of the Fenland peoples and their

change from mainly pastoral to almost purely agricultural life. The principal crop in the eighteenth century was rape, its Fen name "cole". While at present it is only used for feeding purposes, particularly for sheep, its seed was then an extensive source of oil (rape, colza oil, etc.). The Fenland is no longer a grazier's country, but a land of corn, potatoes and beet. Occasionally mustard and buckwheat fields diversify the landscape, and in places horticulture, flower and fruit farmings have been extensively developed. As a whole, the Fens are prosperous, but many areas require scientific treatment, some perhaps a reclaying, others an attention to the water-level, and, surprisingly perhaps, others a retention of ground moisture that the addition of humus alone can give. Can we stimulate Mr. Darby to tell us, out of the abundance of his knowledge, a little of the more human side of the Fenlands, leaving aside for a time the technique of research ? 